\title{
PHENOLIC COMPOSITION, VOLATILE CONSTITUENTS AND ANTIOXIDANT POTENTIAL OF WILD EDIBLE FRUIT ELAEOCARPUS TECTORIUS (LOUR.) POIR. (ELAEOCARPACEAE)
}

\author{
ABHISHEK MUNDARAGI ${ }^{1}$, DEVARAJAN THANGADURAI ${ }^{1}{ }^{*}$, JEYABALAN SANGEETHA $^{2}$, \\ SHIVANAND BHAT ${ }^{3}$
}

${ }^{I}$ Department of Botany, Karnatak University, Dharwad, Karnataka, 580003, India

${ }^{2}$ Department of Environmental Science, Central University of Kerala, Kasaragod, Kerala 671316, India

${ }^{3}$ Department of Botany, Government Arts and Science College, Karwar, Karnataka 581301, India

*corresponding author: drthanga.kud@gmail.com

Manuscript received: February 2017

\begin{abstract}
Elaeocarpus tectorius (Lour.) Poir. is a wild edible fruit of Western Ghats in India, belonging to family Elaeocarpaceae. Ethnobotanically, the plant is known to possess multiple health benefits. In the present study, methanol extract of E. tectorius fruit was screened for total phenolic content, total flavonoid content and antioxidant activity. The in vitro antioxidant activity was evaluated using four different assays: total antioxidant capacity, reducing power assay, 2,2-Diphenyl-1-picrylhydrazyl (DPPH) assay and 2,2'-azino-bis(3-ethylbenzothiazoline-6-sulfonic acid) (ABTS). Further, HPLC and GC-MS analysis was carried out to investigate the potential phenolic acids and volatile constituents present in the fruits. Results indicated that methanol extract of E. tectorius fruit successfully scavenged various free radicals evaluated in a dose dependent manner. HPLC and GC-MS profiling revealed the presence of six vital phenolic acids and twelve volatile constituents, respectively. Thus, observations of the present study offer a preliminary evidence of nutritive value of the E. tectorius, moreover this fruit can serve as a potential source of antioxidants and can be utilized in food and nutraceutical industries.
\end{abstract}

\section{Rezumat}

Elaeocarpus tectorius (Lour.) Poir. este un fruct sălbatic comestibil din India, aparținând familiei Elaeocarpaceae. Din punct de vedere etnobotanic, planta este cunoscută ca având beneficii multiple pentru sănătate. În studiul de față, extractul metanolic obținut din fructul E. tectorius a fost testat pentru determinarea conținutului fenolic și flavonoidic total, precum și a activității antioxidante. Activitatea antioxidantă in vitro a fost evaluată folosind: capacitatea antioxidantă totală, puterea de reducere a 2,2-difenil-1-picrilhidrazil (DPPH) şi a acidului 2,2'-azino-bis(3-etilbenzotiazolin-6-sulfonic) (ABTS). De asemenea, a fost efectuată analiza HPLC și GC-MS pentru a determina posibilii acizi fenolici și compușii volatili prezenți în fruct. Rezultatele au indicat faptul că extractul metanolic din fructul E. tectorius a prezentat acţiune antioxidantă doză dependentă. Profilul HPLC a indicat prezența a șase acizi fenolici, iar GC-MS a indicat prezența a 15 compuşi volatili. Astfel, observațiile studiului de față reprezintă o dovadă preliminară cu privire la valoarea nutritivă a E. tectorius.

Keywords: antioxidant activity, Elaeocarpus tectorius, GC-MS, HPLC, total flavonoid content, total phenolic content, wild fruit

\section{Introduction}

Plants are considered as primary and rich source of medicines. Plants and plant-based products are favourite choice among people across globe, as they are safe and have no side effects. Several medicinal plants are exploited in identification and elucidation of phytochemicals responsible for therapeutic nature. Different parts of plants possess wide array of phytochemicals that are known to have several health benefits such as antimicrobial and antioxidant activity [31]. Fruits are a rich and natural source of nutritional components and antioxidants. Epidemiological studies indicate that regular consumption and high dietary intake of fruits has beneficial effect against several chronic diseases including hypertension, diabetes and several forms of cancer [2, 4, 6, 34]. India is one of the richest tropical biodiversity countries consisting of several indigenous fruits. Western Ghats of Southern India is a biodiversity hotspot known for several indigenous and endemic fruits. Wild edible fruits are abundantly available during their glut season. Availability of nutritive and phytochemical information on these wild edible fruits is very scarce despite the several attempts that have been made in recent past. Fruits constitute good amount of phenolic acids that provide several health benefits other than nutritional fulfilment. The quantity of phenolic acids in fruits is dependent on multiple intrinsic and extrinsic factors including variety, geography, soil and plant health, climate and storage conditions [3, 9]. Phenolic acids are generally classified based on the number of phenol rings, such as stilbenes, flavonoids and tannins. These phenolic compounds consist of single or multiple 
hydroxyl groups directly linked to an aromatic ring. Phenolic acids, namely, caffeic, chlorogenic, ferulic and $p$-coumaric acids are potential antioxidants in comparable to that of hydroxy derivatives of benzoic acid such as $p$-hydroxybenzoic, vanillic and syringic acids [17, 32].

The ability of a molecule to inhibit the oxidation of other molecule is termed as antioxidants. The imbalance between the free radical generation and antioxidant defence mechanism leads to oxidative stress which is considered to be the main cause for many disorders and chronic diseases [1]. Thus, the only prerequisite to avoid oxidative stress is the dietary intake of food rich in antioxidants. Various natural antioxidants present in the plant and plant-based products successfully inhibit oxidation reaction by donating an electron to free radicals generated through oxidative stress [33]. Phenolic acids, coloured pigments and vitamins are natural source of antioxidants, while, synthetic antioxidants such as butylated hydroxyanisole, propyl gallate, tert-butylhydroquinone and butylated hydroxytoluene are all reported to have adverse side effects $[5,28]$. Hence the quest for exploring natural antioxidants is increasing day by day in this context, several attempts are being made by the scientific community.

Elaeocarpus tectorius (Lour.) Poir. (Elaeocarpaceae family) is a tall tree that grows up to 40 meters, found in the higher altitude of the Nilgiris, a part of Western Ghats and UNESCO World Network of Biosphere Reserves. Fruits are green in colour, sweet to taste and commonly available during the months of July to August. Locally, the fruit is called by different names such as bikkihannu and bikkipalzam in Tamil language. Previous studies show that the fruit is known to comprise following nutritive composition: moisture (\%): 59.30, proteins (mg/100 g): 1.4, fibres (mg/100 g): 1.6, phosphorous (mg/100 g): 26.00, iron (mg/100 g): 3.10 , calcium (mg/100 g): 37.00, carotenes $(\mathrm{mg} / 100 \mathrm{~g}): 190.00$, thiamine $(\mathrm{mg} / 100 \mathrm{~g}): 0.02$, niacin $(\mathrm{mg} / 100 \mathrm{~g}): 0.30$ and riboflavin $(\mathrm{mg} / 100 \mathrm{~g}): 0.06$, [20]. Traditionally, fruits are consumed by badagas, a tribal community of Nilgiris forests and it is commonly used against microbial infections and several health issues including rheumatism and piles [20, 25-27]. The aim of this study was to evaluate the total phenolics, total flavonoids, individual phenolic acids, volatile constituents present in the methanolic extract of $E$. tectorius fruit and further assessment of the antioxidant potential by using multiple in vitro assays.

\section{Materials and Methods}

\section{Reagents}

All chemicals used in the present study were of analytical grade. Ascorbic acid, aluminium chloride, potassium ferricyanide, ferric chloride, Folin-Ciocâlteu reagent, sodium carbonate, trichloroacetic acid, glacial acetic acid, sodium phosphate (monobasic and dibasic) and methanol (HPLC grade) were purchased from Merck Chemicals, Mumbai, India. 2, 2-Diphenyl-1picrylhydrazyl (DPPH), 2,2'-Azino-bis(3-ethylbenzothiazoline-6-sulfonic acid) (ABTS) and phenolic acids such as gallic, protocatechuic, chlorogenic, vanillic, caffeic, syringic, $p$-coumaric, ferulic and trans-cinnamic acids were obtained from Sigma-Aldrich Company Ltd. (Bangalore, India).

\section{Plant material and sample preparation}

Mature and healthy fruits of E. tectorius were collected from Nilgiri hills of Ooty in Tamil Nadu, India. An identified plant specimen was deposited at the Herbarium of Department of Botany, Karnatak University, Dharwad, India (KU/AM/DT-012). Fruits were washed with deionized water, cleaned, chopped in to small pieces, oven dried at $45 \pm 2{ }^{\circ} \mathrm{C}$ and dried samples was crushed in to fine powder. Extraction was then carried out using methanol as a solvent in a sonicator at keeping a ratio of 1:10, sample and solvent, respectively. Further it was centrifuged at $10,000 \mathrm{rpm}$ at $4^{\circ} \mathrm{C}$ for $15 \mathrm{~min}$. The homogenate was filtered through polytetrafluoroethylene (PTFE) membrane filter $(0.45 \mu \mathrm{m})$. Finally, the sample was completely dried in a rotary evaporator.

\section{Estimation of total phenolic content}

The total phenolic content in the methanolic fruit extract of E. tectorius was determined following the protocol described by Kumar et al. [14]. Known aliquots of methanol extract and standards $(1 \mathrm{mg} / \mathrm{mL})$ were taken in separate test tubes and volume was made up to $3 \mathrm{~mL}$ by adding deionized water. FolinCiocâlteu's reagent $(0.5 \mathrm{~mL})$ was mixed to each tube and incubated for $3 \mathrm{~min}$ at room temperature, a solution of sodium carbonate $(20 \%, 2 \mathrm{~mL})$ was added, thoroughly mixed and further these tubes were kept in boiling water bath for $1 \mathrm{~min}$. Absorbance was recorded at $650 \mathrm{~nm}$ using a double beam UV-Visible Spectrophotometer (UV-1800, Shimadzu, Japan) against a blank reagent and calibration curve was plotted using various concentrations of gallic acid $(20-100 \mu \mathrm{g} / \mathrm{mL})$ and expressed as milligrams of gallic acid equivalents per gram dry weight (mg GAE/g dw).

Estimation of total flavonoid content

Estimation of flavonoid content in the sample was done following the protocol described by Helmja et al. [10], with slight variation in reaction volumes. Briefly, methanolic fruit extract $(500 \mu \mathrm{g} / \mathrm{mL})$ and standards were pipetted out in a separate test tubes and volume was made up to $0.5 \mathrm{~mL}$ with deionized water. Sodium nitrite $(5 \% ; 0.03 \mathrm{~mL})$ was added to each tube, after $5 \mathrm{~min}$ incubation at room temperature, aluminium chloride solution $(10 \% ; 0.06 \mathrm{~mL})$ was added, incubated for $5 \mathrm{~min}$ at room temperature and further sodium hydroxide solution $(1 \mathrm{M}, 0.2 \mathrm{~mL})$ was mixed and total volume was made up to $1 \mathrm{~mL}$ with deionized water by adding $0.210 \mathrm{~mL}$. Absorbance 
FARMACIA, 2019, Vol. 67, 2

was measured at $510 \mathrm{~nm}$ against a blank reagent. A calibration curve was prepared using different concentrations of catechin $(20-100 \mu \mathrm{g} / \mathrm{mL})$. From the standard curve, concentration of flavonoids in the methanolic fruit extract was determined and expressed as milligrams of catechin equivalents per gram dry weight (mg CE/g dw).

\section{Total antioxidant capacity}

Determination of total antioxidant activity was done following a method of Prieto et al. [24] with a slight modification in the reaction mixture. Briefly, $0.2 \mathrm{~mL}$ of methanolic fruit extract was taken in a test tube. To this, $1.8 \mathrm{~mL}$ of reagent solution $(0.6 \mathrm{M}$ sulfuric acid, $28 \mathrm{mM}$ sodium phosphate, and $4 \mathrm{mM}$ ammonium molybdate) was added. The tubes were kept at $95^{\circ} \mathrm{C}$ for $90 \mathrm{~min}$ in a water bath and allowed to cool. The absorbance was measured at $695 \mathrm{~nm}$ against a blank reagent using double beam UV-Vis spectrophotometer (UV-1800, Shimadzu, Japan). The values are represented as $\mu \mathrm{g}$ ascorbic acid equivalents (AAE) per gram dry weight.

\section{Reducing power activity}

Determination of reducing power activity of methanol extract was done following the method of Oyaizu [21]. Different concentrations of sample (200 - $1000 \mu \mathrm{g} / \mathrm{mL}$, made up to $1.0 \mathrm{~mL}$ with methanol) was mixed with freshly prepared $2.5 \mathrm{~mL}$ of phosphate buffer $(0.2 \mathrm{M}$, $\mathrm{pH}$ 6.6) and $2.5 \mathrm{~mL}$ of potassium ferricyanide (1\%), and this was kept at $50^{\circ} \mathrm{C}$ for $20 \mathrm{~min}$ in a water bath allowing the reaction to complete. After incubation period, $2.5 \mathrm{~mL}$ of $10 \%$ trichloroacetic acid was added, further this was centrifuged at $650 \mathrm{rpm}$ for $10 \mathrm{~min}$. Supernatant $(2.5 \mathrm{~mL})$ was mixed with deionized water $(2.5 \mathrm{~mL})$ and further $0.5 \mathrm{~mL}$ of $\mathrm{FeCl}_{3}(0.1 \%)$ was added. Finally, absorbance was read at $700 \mathrm{~nm}$ using a double beam UV-Visible Spectrophotometer (UV1800, Shimadzu, Japan).

DPPH radical scavenging activity

DPPH radical scavenging activity of methanolic fruit extract of E. tectorius was determined spectrophotometrically following the protocol of Lee et al. [15] and Jagtap et al. [11]. DPPH solution (24 mg dissolved in $100 \mathrm{~mL}$ of methanol) was further diluted with methanol until the absorbance was achieved to $1.1 \pm 0.01$ units at $517 \mathrm{~nm}$ using a double beam UVVisible spectrophotometer (UV-1800, Shimadzu, Japan). $3 \mathrm{~mL}$ of DPPH solution was mixed to various concentrations of sample $(200-1000 \mu \mathrm{g} / \mathrm{mL})$, vortexed and incubated for $30 \mathrm{~min}$ at $37 \pm 2{ }^{\circ} \mathrm{C}$ in dark. Methanol with no added samples was taken as control. Percentage radical scavenging activity (RSA) was calculated using the formula:

$$
\% \operatorname{RSA}=\left[\left(\mathrm{A}_{\text {control }}-\mathrm{A}_{\text {sample }}\right) / \mathrm{A}_{\text {control }}\right] \times 100,
$$

where, $\mathrm{A}=$ absorbance at $517 \mathrm{~nm}$.
ABTS assay

ABTS assay was done following the procedure described by Thaipong et al. [30] with slight variation in the reaction volume. Preparation of stock solutions was done by taking 7.4 mM ABTS solution and $2.6 \mathrm{mM}$ potassium persulfate solution. Working solution was prepared by mixing these two stock solutions in equal volume and reaction mixture was kept for incubation in dark at room temperature. Finally, this solution was diluted by taking $1 \mathrm{~mL}$ reacted ABTS solution with $60 \mathrm{~mL}$ methanol to obtain an absorbance of $1.170 \pm$ 0.02 units at $734 \mathrm{~nm}$ using a double beam UVVisible Spectrophotometer (UV-1800, Shimadzu, Japan). For each assay, ABTS solution was prepared freshly. A $300 \mu \mathrm{L}$ of various concentrations of fruit extract was mixed with $2700 \mu \mathrm{L}$ of the ABTS working solution, which was allowed to react in dark. Finally, absorbance was read at $734 \mathrm{~nm}$.

HPLC analysis of phenolic acids

HPLC analysis was performed with the aid of liquid chromatograph multi gradient system equipped with manual injector and a diode-array detector (LC-10A, Shimadzu, Japan). The analytical column was a C18 column $(250 \times 4.6 \mathrm{~mm})$ packed with $5 \mu \mathrm{m}$ particle size. Solvent A consisted of acetonitrile whereas solvent B consisted of $2 \%$ acetic acid in water. Gradient profile was followed according to the method of Kim et al. [13]: $100 \% \mathrm{~B}$ to $85 \% \mathrm{~B}$ in $30 \mathrm{~min}, 85 \% \mathrm{~B}$ to $50 \% \mathrm{~B}$ in $20 \mathrm{~min}, 50 \% \mathrm{~B}$ to $0 \% \mathrm{~B}$ in $5 \mathrm{~min}$ and $0 \% \mathrm{~B}$ to $100 \% \mathrm{~B}$ in $5 \mathrm{~min}$, flow rate of $1.0 \mathrm{~mL} / \mathrm{min}$ was maintained and sample volume of $10 \mu \mathrm{L}$ was injected with a total programme run time of $70 \mathrm{~min}$ and simultaneous observation at 280 and $320 \mathrm{~nm}$. Phenolic acids in sample were identified and quantified by comparing peaks with that of the congruent retention time of reference standards; that were spiked instantly after sample analysis.

GC-MS analysis

GC-MS analysis of the methanol extract of E. tectorius fruit was done following the procedure described by Geetha et al. [7]. Briefly, GC-MS (GCMS-QP2010, Shimadzu, Japan) equipped with fused silica capillary column (Rtx-5MS, crossbond diphenyl dimethyl polysiloxane) was used for GC-MS detection with an electron ionization system at ionization energy of $-70 \mathrm{eV}$. Helium (99.999\%) was used as carrier gas with a flow rate of $1 \mathrm{~mL} / \mathrm{min}$ and sample volume injected was $1 \mu \mathrm{L}$. Injector temperature and ion source temperature was set to $250^{\circ} \mathrm{C}$ and $200^{\circ} \mathrm{C}$, respectively. The oven temperature was programmed at $110^{\circ} \mathrm{C}$ to $200^{\circ} \mathrm{C}$ with a rate of $10^{\circ} \mathrm{C} / \mathrm{min}$ and with a final temperature of $260^{\circ} \mathrm{C}$ at $5^{\circ} \mathrm{C} / \mathrm{min}$. Interface temperature was kept at $250^{\circ} \mathrm{C}$. Compounds were identified based on the retention time, retention index, mass spectra of each putative compound with those of the NIST library (2005). The area percentage of the identified compounds was expressed in terms of percentage with peak area normalization. 
Statistical analysis

All assays were carried out in triplicate and results were represented as mean \pm standard deviation (SD) on a dry weight basis. Statistical analysis was carried out with XLSTAT software (2014.5.03, Addinsoft, NY) using ANOVA and differences at $p<0.05$ were considered significant.

\section{Results and Discussion}

Phenolic acids as secondary metabolites are found abundantly and naturally in various parts of plants.
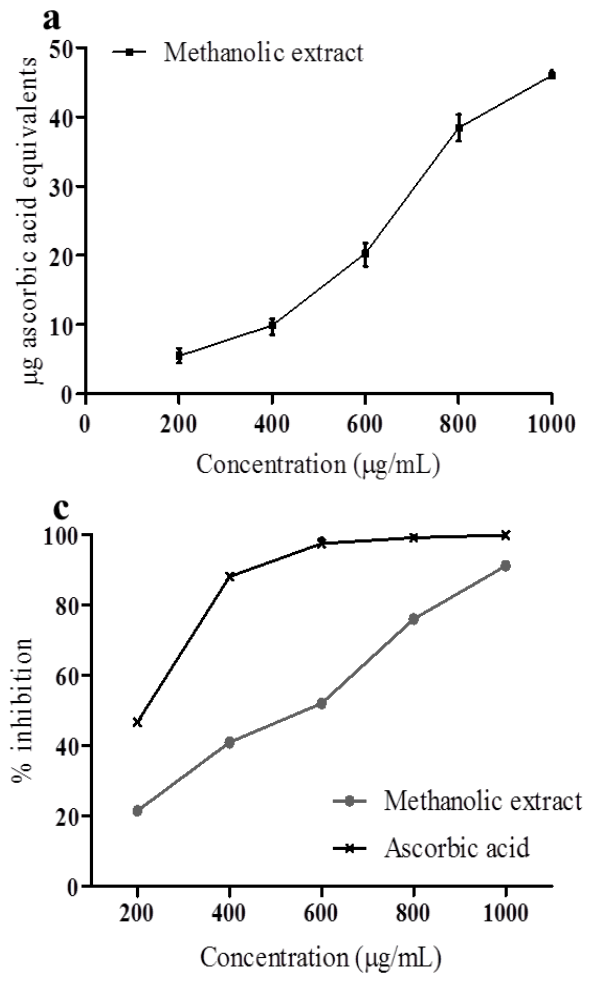

Fruits constitute several vital phenolic acids and are responsible for taste, colour, aroma and flavour. Several epidemiological studies have proved that dietary intake of fruits rich in phenolic acids is known to be beneficial against several chronic degenerative diseases. Therefore, till to date more than 8000 polyphenols have been identified and their biological significance is being investigated [22]. In the present study, the total phenolic and flavonoid content observed in the methanolic extract of E. tectorius fruit was $10.96 \pm 0.14 \mathrm{mg} \mathrm{GAE} / \mathrm{g} \mathrm{dw}$ and $1.25 \pm 0.04 \mathrm{mg} \mathrm{CE} / \mathrm{g} \mathrm{dw}$, respectively.
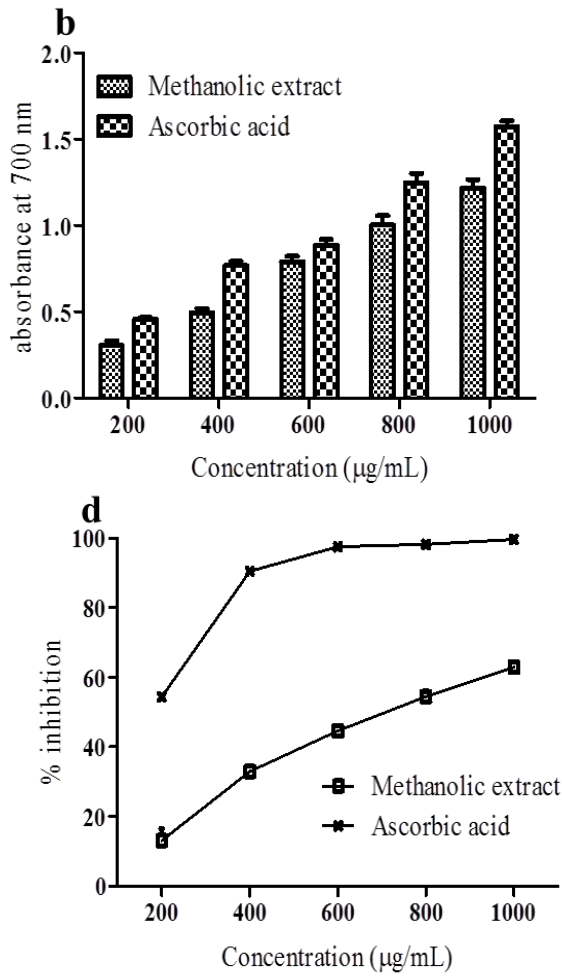

Figure 1.

Antioxidant activity of methanolic fruit extract of E. tectorius against various radicals: (a) Total antioxidant activity,

(b) Reducing power effect, (c) DPPH radical scavenging activity and (d) ABTS radical scavenging activity

Total antioxidant activity was determined by phosphomolybdenum method and expressed as mg ascorbic acid equivalents (AAE)/g dw. The methanolic fruit extract comprised a good proportion of antioxidant capacity (Figure 1a). However, the methanol fruit extract had $10.626 \mathrm{mg}$ ascorbic acid equivalents/g dw. The reducing power ability of the extract is dependent upon the reducing agents present in it. The methanol extract exhibited a significant reducing power effect signifying that it comprises fair amount of reducing agents (Figure 1b). Higher absorbance values indicate higher reducing power ability. Thus, the methanolic fruit extract of E. tectorius showed higher reducing power with increased concentration. The DPPH assay is a simple, fast and one of the oldest techniques, which is widely accepted and employed for assessing the antioxidant activity of particular test sample. Generally, 2,2-diphenyl-1-picrylhydrazyl reacts with hydrogen donors such as phenolic acids and vitamins present in the test sample. The intensity of the change in colour of DPPH reaction mixture increases with the increasing concentrations of the test sample. The disappearance of colour is predominantly dependent on the presence of the antioxidants such as phenolic acids and vitamins in the sample. The radical scavenging activity of methanol fruit extract exhibited strongest inhibition at the concentration of $1000 \mu \mathrm{g} / \mathrm{mL}$ with a $92.91 \pm 0.18 \%$ of RSA (Figure $1 \mathrm{c}$ ). The $\mathrm{IC}_{50}$ value for the DPPH radical was found to be $571.7 \pm 2.04$ $\mu \mathrm{g} / \mathrm{mL}$. The ABTS assay is considered as a best tool to define the antioxidant ability of bioactive compounds. Many recent reports prove that plant extracts comprise various phenolic acids that are responsible for the antioxidant activity against ABTS free radicals. In the present study, methanolic fruit extract of E. tectorius exhibited a potential scavenging activity against ABTS 
radicals (Figure 1d) with an $\mathrm{IC}_{50}$ value of $469.0 \pm$ $1.82 \mu \mathrm{g} / \mathrm{mL}$. This may be attributed to the presence of vital phenolic acids and bioactive constituents in the fruit.

Individual phenolic acids in methanolic fruit extract of E. tectorius were detected by HPLC (Figure 2). The major peaks were identified by comparison with nine standard phenolic acids spiked (Figure 2a), in which phenolic acids such as gallic $(29.53 \%)$, vanillic $(3.423 \%)$, syringic $(4.461 \%)$, $p$-coumaric $(7.241 \%)$, ferulic $(5.680 \%)$ and trans-cinnamic acids $(10.93 \%)$ were found (Figure 2b). However, phenolic acids, viz., caffeic acid, chlorogenic acid and protocatechuic acid were not detected among the standards analysed. Although, unknown major peaks at $13^{\text {th }}$ and $50^{\text {th }} \mathrm{min}$ with an area \% of 23.266 and 10.495 , respectively, were also detected. Prakash et al. [23] reported the presence of three phenolic acids in wild edible fruit, E. sikkimese, viz., caffeic, ferulic and gallic acids. However, in the current study, E. tectorius showed wide array of phenolic acids.

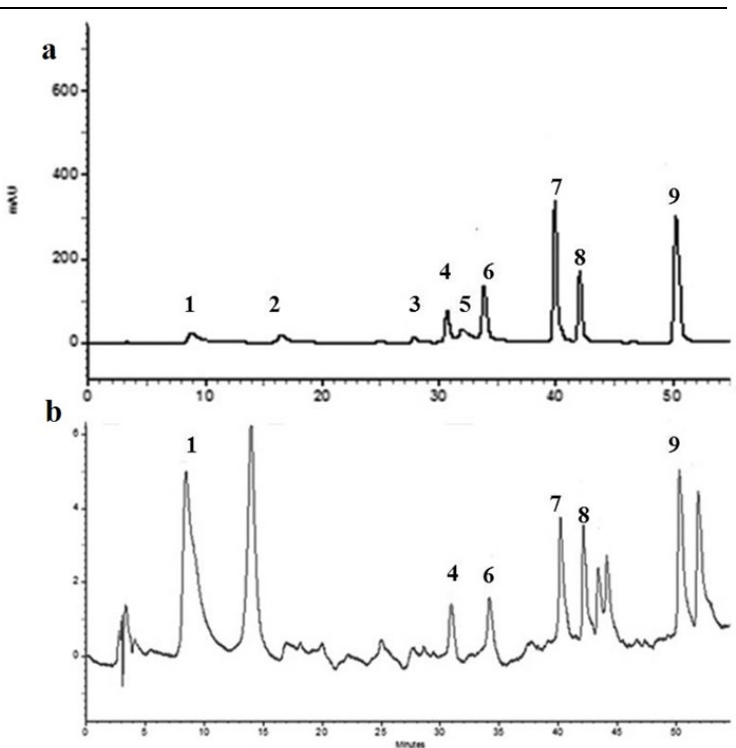

Figure 2.

HPLC chromatogram depicting standard phenolic acids (a) and methanolic fruit extract E. tectorius (b) at 280 $\mathrm{nm}$ : (a) highlights chromatogram of standard phenolics, viz. (1) gallic, (2) protocatechuic, (3) chlorogenic, (4) vanillic, (5) caffeic, (6) syringic, (7) $p$-coumaric, (8) ferulic, and (9) trans-cinnamic acids; (b) corresponds to phenolic acids detected in methanolic fruit extract of E. tectorius.

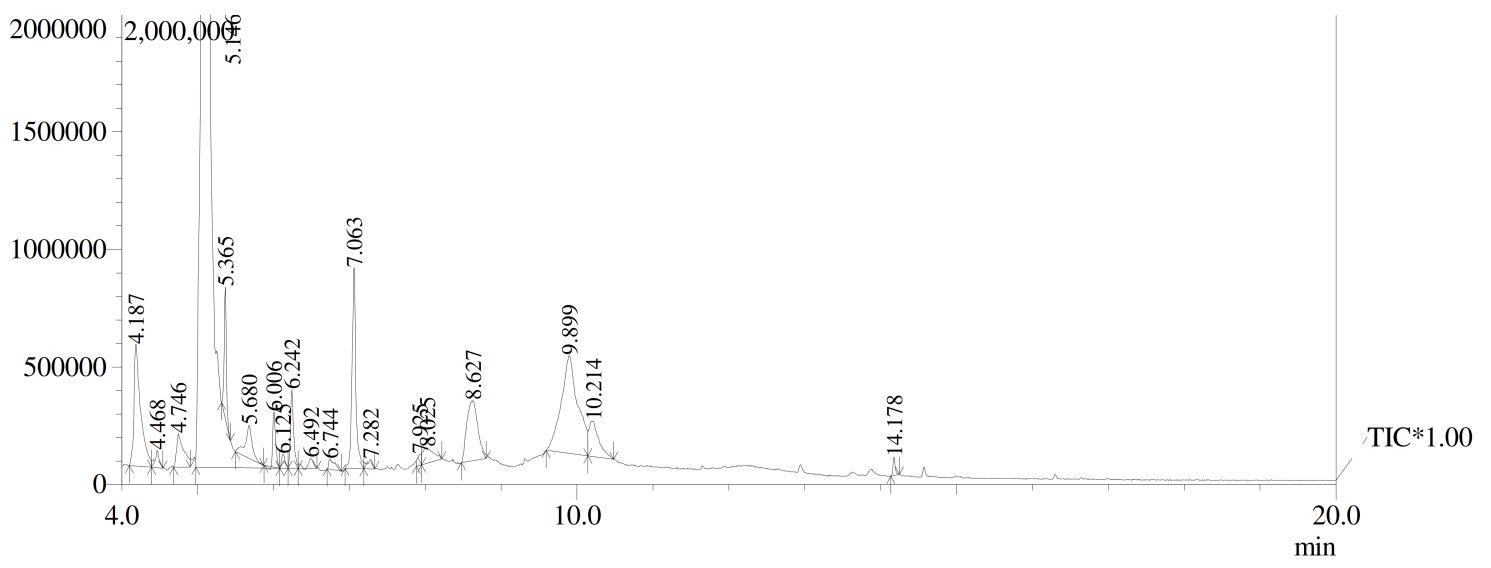

Figure 3.

GC-MS chromatogram of methanolic fruit extract of E. tectorius

The volatile constituents present in the methanolic fruit extract of E. tectorius were detected by GC-MS analysis (Figure 3 ) with a total run time of 35 minutes. 12 compounds were identified with the aid of mass spectra and comparison with NIST library. The predominant compounds retention time, retention index, area (\%), molecular formula, molecular weight and nature of compound are presented in Table I. Among the identified volatile constituents, 5-hydroxymethyl- furfural, 1,6-anhydro- $\beta$-D-glucopyranose and 1,5anhydro-D-mannitol were predominant. Several studies indicate that dry fruits are rich source of 5-hydroxymethylfurfural, whereas some studies indicate the adverse effects of 5-HMF as well [8, 18, 25]. Recent studies suggest that 5-HMF may possess several favourable bioactivities including in vitro antioxidant, antimutagenic and antihypoxic activities [12, 16, 19, 29, 35]. 
GC-MS profiling of methanolic fruit extract of E. tectorius

\begin{tabular}{clccccc}
\hline $\begin{array}{c}\text { Retention } \\
\text { time (min) }\end{array}$ & \multicolumn{1}{c}{ Compound name } & $\begin{array}{c}\text { Retention } \\
\text { index }\end{array}$ & $\begin{array}{c}\text { Area } \\
\text { \% }\end{array}$ & $\begin{array}{c}\text { Molecular } \\
\text { formula }\end{array}$ & $\begin{array}{c}\text { Molecular } \\
\text { weight }\end{array}$ & $\begin{array}{c}\text { Nature of } \\
\text { compound }\end{array}$ \\
\hline 4.746 & 1,5-Anhydro-D-mannitol & 672 & 8.30 & $\mathrm{C}_{6} \mathrm{H}_{12} \mathrm{O}_{5}$ & 164.15 & Sugar \\
\hline 5.146 & 2-Methylcyclopentanone & 729 & 1.28 & $\mathrm{C}_{6} \mathrm{H}_{10} \mathrm{O}$ & 98.14 & Ketone \\
\hline 5.365 & 3-Heptanol & 884 & 0.26 & $\mathrm{C}_{7} \mathrm{H}_{16} \mathrm{O}$ & 116.20 & Alcohol \\
\hline 5.680 & 5-Hydroxymethylfurfural & 956 & 39.94 & $\mathrm{C}_{6} \mathrm{H}_{6} \mathrm{O}_{3}$ & 126.11 & Aldehyde \\
\hline 6.006 & Hexanoic acid & 967 & 1.77 & $\mathrm{C}_{6} \mathrm{H}_{12} \mathrm{O}_{2}$ & 116.16 & Fatty acid \\
\hline 6.125 & 6-Oxoheptanoic acid & 1022 & 1.17 & $\mathrm{C}_{7} \mathrm{H}_{12} \mathrm{O}_{3}$ & 144.16 & Keto acid \\
\hline 6.242 & 3-Hydroxy-2-methyl-4-pyrone & 1061 & 0.75 & $\mathrm{C}_{6} \mathrm{H}_{6} \mathrm{O}_{3}$ & 126.11 & Flavone \\
\hline 6.492 & 4-Methylhexyl acetate & 1267 & 0.22 & $\mathrm{C}_{9} \mathrm{H}_{18} \mathrm{O}_{2}$ & 158.24 & Alcohol \\
\hline 7.925 & 1H-Azonine, octahydro-1-nitroso- & 1526 & 1.42 & $\mathrm{C}_{8} \mathrm{H}_{16} \mathrm{~N}_{20}$ & 119.16 & Nitro compound \\
\hline 9.899 & Hexadecanoic acid & 1959 & 0.21 & $\mathrm{C}_{16} \mathrm{H}_{32} \mathrm{O}_{2}$ & 256.42 & Fatty acid \\
\hline 10.214 & 5-(2-Propynyloxy)-2-pentanol & 2273 & 0.28 & $\mathrm{C}_{8} \mathrm{H}_{14} \mathrm{O}_{2}$ & 142.19 & Alcohol \\
\hline 14.178 & 4-(1-Hydroxyethyl)- $\gamma$-butanolactone & 2348 & 1.20 & $\mathrm{C}_{6} \mathrm{H}_{10} \mathrm{O}_{3}$ & 130.14 & Furanone \\
\hline
\end{tabular}

\section{Conclusions}

The quantitative estimation of the methanolic fruit extract of E. tectorius showed the presence of total phenolic content and total flavonoid content of $10.96 \pm 0.14 \mathrm{mg} \mathrm{GAE} / \mathrm{g} \mathrm{dw}$ and $1.25 \pm 0.04 \mathrm{mg}$ $\mathrm{CE} / \mathrm{g} \mathrm{dw}$, respectively. Moreover, HPLC analysis revealed it to be a good source of various vital phenolic acids, viz., gallic, vanillic, syringic, ferulic, $p$-coumaric and trans-cinnamic acids. Further, GCMS profiling indicated the presence of various volatile constituents wherein 5-hydroxymethylfurfural was found to be the major compound. Methanolic fruit extract of E. tectorius exhibited potential antioxidant activity against various free radicals assayed, which may be attributed to the phenolics and flavonoids present in the fruit. In conclusion, the observed results offer nutraceutical significance of the fruit that can be utilized in the food industry. Nevertheless, extensive study is essential in order to exploit the potential bioactivities of E. tectorius fruit against certain diseases as traditionally it is acclaimed.

\section{Acknowledgement}

Authors acknowledge the financial aid received from University Grants Commission, Government of India under UGC-UPE(Non-NET)-Fellowship (KU/Sch/ UGC-UPE/2014-2015/873).

\section{References}

1. Abhishek M, Thangadurai D, Proximate composition, nutritive value and antioxidant activity of Flacourtia montana J. Graham. (Salicaceae). Vegetos, 2015; 28: 181-187.

2. Aguilera Y, Martin-Cabrejas MA, González de Mejia E, Phenolic compounds in fruits and beverages consumed as part of the Mediterranean diet: their role in prevention of chronic diseases. Phytochem Rev., 2016; 15: 405-423.

3. Belitz HD, Grosch W, Schieberle P, Food Chemistry. Springer-Verlag: Berlin, Heidelberg, 2009; 806-860.
4. Boeing H, Bechthold A, Bub A, Ellinger S, Haller D, Kroke A, Critical review: vegetables and fruit in the prevention of chronic diseases. Eur J Nutr., 2012; 51(6): 637-663.

5. Bouayed J, Bohn T, Exogenous antioxidants doubleedged swords in cellular redox state: health beneficial effects at physiologic doses versus deleterious effects at high doses. Oxid Med Cell Longev., 2010; 3(4): 228-237.

6. Carter P, Gray LJ, Troughton J, Khunti K, Davies MJ, Fruit and vegetable intake and incidence of type 2 diabetes mellitus: systematic review and metaanalysis. BMJ., 2010; 341: c4229: 1-8.

7. Geetha D, Rajeswari M, Jayashree I, Chemical profiling of Elaeocarpus serratus L. by GC-MS. As Pac J Trop Biomed., 2013; 3(12): 985-987.

8. Ghosh G, Panda P, Rath M, Pal A, Sharma T, Das D, GC-MS analysis of bioactive compounds in the methanol extract of Clerodendrum viscosum leaves. Pharmacog Res., 2015; 7(1): 110-113.

9. Haminiuk CWI, Maciel GM, Plata-Oviedo MSV, Peralta RM, Phenolic compounds in fruits - an overview. Int J Food Sci Tech., 2012; 47: 2023-2044.

10. Helmja K, Vaher M, Gorbatšova J, Kaljurand M, Characterization of bioactive compounds contained in vegetables of the Solanaceae family by capillary electrophoresis. Proceed Estonian Acad Sci., 2007; 56(4): 172-186.

11. Jagtap UB, Panaskar SN, Bapat VA, Evaluation of antioxidant capacity and phenol content in Jackfruit (Artocarpus heterophyllus Lam.) fruit pulp. Plant Foods Hum Nutr., 2010; 65: 99-104.

12. Janzowski C, Glaab V, Samimi E, Schlatter J, Eisenbrand G, 5-Hydroxymethylfurfural: assessment of mutagenicity, DNA-damaging potential and reactivity towards cellular glutathione. Food Chem Toxicol., 2000; 38: 801-809.

13. Kim KH, Tsao R, Yang R, Cui SW, Phenolic acid profiles and antioxidant activities of wheat bran extracts and the effect of hydrolysis conditions. Food Chem., 2006; 95: 466-473.

14. Kumar S, Kumar D, Man J, Saroha K, Singh N, Vashishta B, Antioxidant and free radical scavenging potential of Citrullus colocynthis (L.) Schrad. methanolic fruit extract. Acta Pharmaceutica, 2008; 58(2): 215220. 
FARMACIA, 2019, Vol. 67, 2

15. Lee HC, Kim JH, Jeong SM, Kim DR, Ha JU, Nam $\mathrm{KC}$, Effect of far infrared radiation on the antioxidant activity of rice hulls. J Agric Food Chem., 2003; 51(15): 4400-4403.

16. Li MM, Wu LY, Zhao T, Xiong L, Huang X, Liu $\mathrm{ZH}$, The protective role of 5-HMF against hypoxic injury. Cell Stress Chaperones, 2011; 16: 267-273.

17. Mattila P, Kumpulainen J, Determination of free and total phenolic acids in plant-derived foods by HPLC with diode-array detection. J Agric Food Chem., 2002; 50(13): 3660-3667.

18. Monien BH, Herrmann K, Meinl W, Glatt HR, Furfuryl alcohol: mutagenicity and DNA adducts in Salmonella typhimurium strains expressing human sulfotransferase $1 \mathrm{~A} 1$ and formation of the same adducts in mouse tissues in vivo. Carcinogenesis, 2011; 32: 1533-1539.

19. Mousavi R, Alizadeh M, Saleh-Ghadimi S, Consumption of 5-hydroxymethylfurfural-rich dried fruits is associated with reduction in urinary excretion of 8-hydroxy-2'deoxyguanosine: a randomized clinical trial. Eur Food Res Technol., 2016; 242: 677-684.

20. Nayagam MC, Pushparaj MS, Rajan S, Less known edible fruit yielding plants of Nilgiris. Ancient Science of Life, 1993; 12: 363-376.

21. Oyaizu M, Studies on products of browning reactions: antioxidant activities of products of browning reaction prepared from glucose amine. Jap J Nutr., 1986; 44: 307-315.

22. Pandey KB, Rizvi SI, Plant polyphenols as dietary antioxidants in human health and disease. Oxid Med Cell Longev., 2009; 2(5): 270-278.

23. Prakash D, Upadhyay G, Gupta C, Pushpangadan P, Singh KK, Antioxidant and free radical scavenging activities of some promising wild edible fruits. Int Food Res J., 2012; 19(3): 1109-1116.

24. Prieto P, Pineda M, Aguilar M, Spectrophotometric quantitation of antioxidant capacity through the formation of a phosphomolybdenum complex: specific application to the determination of vitamin E1. Anal Biochem., 1999; 269(2): 337-341.

25. Ragunathan M, Senthamarai RB, Pharmacognostical studies on the fruit of Elaeocarpus oblongus Gaertn. Pharmacog J., 2014; 6: 72-78.
26. Sathyavathi R, Janardhanan K, Wild edible fruits used by Badagas of Nilgiri District, Western Ghats, Tamilnadu, India. J Med Plants Res., 2014; 8(2): 128-132.

27. Sharvani KA, Devaki NS, Distinct characters of Elaeocarpus, a conservation dependent endemic genus of Western Ghats. Acta Biologica Indica, 2014; 3: 663-667.

28. Shebis Y, Iluz D, Kinel-Tahan Y, Dubinsky Z, Natural antioxidants: function and sources. Food Nutr Sci., 2013; 4: 643-649.

29. Svendsen C, Husøy T, Glatt H, Paulsen JE, Alexander J, 5-Hydroxymethylfurfural and 5-sulfooxymethylfurfural increase adenoma and flat ACF number in the intestine of Min/1 mice. Anticancer Res., 2009; 29: 1921-1926.

30. Thaipong K, Boonprakob U, Crosby K, CisnerosZevallos L, Byrne DH, Comparison of ABTS, DPPH, FRAP, and ORAC assays for estimating antioxidant activity from guava fruit extracts. J Food Comp Anal., 2006; 19(6-7): 669-675.

31. Vaidya ADB, Devasagayam TPA, Current status of herbal drugs in India: an overview. $J$ Clin Biochem Nutr., 2007; 41: 1-11.

32. Velioglu YS, Mazza G, Gao L, Oomah BD, Antioxidant activity and total phenolics in selected fruits, vegetables, and grain products. J Agric Food Chem., 1998; 46: 4113-4117.

33. Vicaș L, Teuşdea A, Vicaş S, Marian E, Jurca T, Mureşan M, Gligoret F, Assessment of antioxidant capacity of some extracts for further use in therapy. Farmacia, 2015; 63(2): 267-274.

34. Wang X, Ouyang Y, Liu J, Zhu M, Zhao G, Bao W, Fruit and vegetable consumption and mortality from all causes, cardiovascular disease, and cancer: systematic review and dose-response meta-analysis of prospective cohort studies. BMJ., 2014; 349: g4490: 1-14.

35. Zhao L, Chen J, Su J, Li L, Hu S, Li B, In vitro antioxidant and antiproliferative activities of 5hydroxymethylfurfural. J Agric Food Chem., 2013; 61: 10604-10611. 